\title{
Necrológio
}

\section{SEBASTIÃO JOSÉ DE OLIVEIRA}

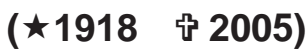

\section{Maria Conceição Messias}

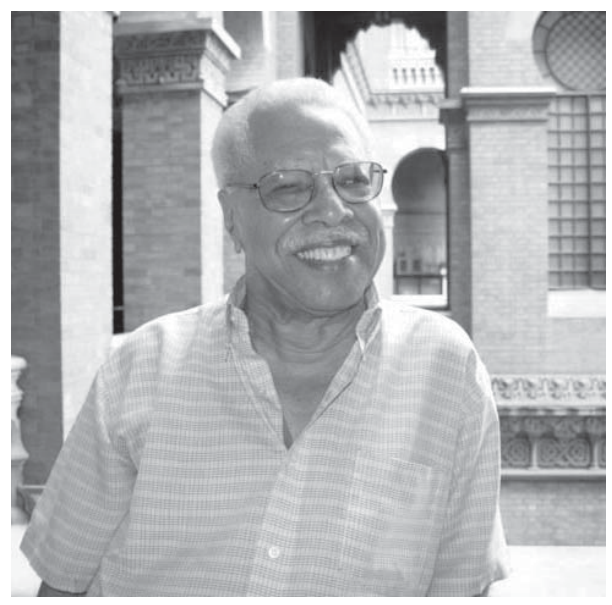

Faleceu em 16 de abril de 2005, na cidade do Rio de Janeiro, Sebastião José de Oliveira, entomólogo e professor do Instituto Oswaldo Cruz. Foram 65 anos dedicados à ciência e ao ensino. Foi o primeiro cientista negro do Instituto Oswaldo Cruz, onde iniciou suas atividades em 1939, como discípulo de Hugo de Souza Lopes e formouse em Medicina Veterinária, em 1941, na Escola Nacional de Veterinária (atual Universidade Federal Rural do Rio de Janeiro). Além do seu vasto conhecimento entomológico, Sebastião José de Oliveira foi especialista na ordem Diptera sobre a qual publicou cerca de 100 artigos científicos principalmente sobre as famílias Chironomidae, Culicidae, Ephydridae e na ordem Strepsiptera em colaboração com Marcos Kogan. Em 1970, foi obrigado a afastar-se do Instituto Oswaldo Cruz, forçado pelo Ato Institucional n.. 5, de $1^{\circ}$ de abril de 1970, que suspendeu os direitos políticos de 10 pesquisadores, três dos quais do Departamento de Entomologia.

Departamento de Entomologia, Instituto Oswaldo Cruz, Av. Brasil 4365, CEP: 21040900, Manguinhos, Rio de Janeiro, RJ, Brasil. E-mail: mmessias@ioc.fiocruz.br 
O episódio foi relatado por Herman Lent, um dos cassados, em seu livro intitulado "Massacre de Manguinhos". Retornou ao Instituto Oswaldo Cruz com a anistia, à convite de Sérgio Arouca e assumiu a Curadoria da Coleção Entomológica, cargo em que permaneceu até a sua morte.

Seu nome foi imortalizado através do gênero Oliveiriellae 10 espécies de insetos, que receberam o nome oliveirai, em homenagem à sua contribuição à Ciência.

Sebastião José de Oliveira foi não só o mestre, o exemplo de profissional ético e competente, mas um grande amigo. Nossas vidas foram também marcadas pelo cavalheirismo ao atender à todos, que o procuravam; por sua alegria ao falar da Portela, "a escola de samba do coração" e do Flamengo, time de futebol do qual era torcedor; pelo seu jeito brincalhão de comentar o cotidiano, pela sua risada, pela sua extraordinária memória e por suas histórias, que nos costumava contar durante o café da tarde. Em nossos ouvidos estarão sempre as lições de vida, que de outros aprendeu e lutava para honrar: "é preciso não esmorecer, para não desmerecer" (Oswaldo Cruz); "a melhor resposta aos momentos de adversidade é o trabalho" ( Hugo de Souza Lopes); "na vida, muitas vezes é preferível perder tudo do que compactuar com uma indignidade" (Herman Lent).

Outros detalhes sobre sua vida estão relatados na biobibliografia publicada em 2000, na Revista Entomologia y Vectores, volume 7, fascículo 3. 